\title{
Synthesis
}

\section{An Indicator Framework for Assessing Agroecosystem Resilience}

\author{
$\underline{\text { Joshua F. Cabell }}^{1}$ and $\underline{\text { Myles Oelofse }}{ }^{2}$
}

\begin{abstract}
Taking departure in the theory of resilience in social-ecological systems, we present an analysis and discussion of how resilience theory can be applied to agroecosystems. Building on the premise that agroecosystems are too complex for resilience to be measured in any precise manner, we delineate behavior-based indicators of resilience within agroecosystems. Based on a review of relevant literature, we present and discuss an index of 13 such indicators, which, when identified in an agroecosystem, suggest that it is resilient and endowed with the capacity for adaptation and transformation. Absence of these indicators identifies points of intervention for managers and stakeholders to build resilience where there is vulnerability. The indicators encompass various phases in the adaptive cycle and seek to link core aspects of social-ecological systems. We stress the strong societal need for building resilience in agroecosystems and advocate for a broader way of evaluating resilience in agroecosystems.
\end{abstract}

Key Words: adaptive cycle; agroecosystems; behavior-based indicators; resilience; social-ecological systems

\section{INTRODUCTION}

The global food system is experiencing rapid and dramatic changes concurrent with global social-political and ecological changes. However, this is nothing new, as societies have experienced rises, falls, and shifts in food production and availability ever since humans sowed the first crops (Diamond 2005, Carpenter et al. 2006). As philosophers and scientists from Heraclitus to Gunderson and Holling have observed, change is one of the few inevitabilities of life. What sets apart the changes occurring today are the rate, magnitude, and genesis of the changes, and the fact that we have the capacity to anticipate and possibly influence the trajectories of these changes (Holling 2001). In terms of the global food system, changes in climate, increased economic disparity, political instability, and shifting consumption patterns have repercussions that are causing nearly one billion people to go hungry while one billion more suffer from obesity worldwide. The loss of freshwater resources, erosion of topsoil, and general degradation of ecosystem services are further undermining the ability of humans to meet their nutritional needs (Millennium Ecosystem Assessment 2005, Carpenter et al. 2006, McIntyre et al. 2009). As the human population approaches nine billion by the mid-21st, as diets shift to demand more meat products and as the discovery of new oil reserves, upon which modern agriculture relies, reaches a plateau, there is a pressing need to find new paths to both food security and resource conservation (Gliessman 2007, Ericksen 2008).

The theory of resilience in social-ecological systems, as first described by Holling (1973) and developed further by others representing a wide range of fields, offers a useful framework for understanding the dynamic relationship between humans and the environment (their so-called social-ecological systems, or SESs), and provides models for increasing society's capacity to manage change. Essentially, resilience is measured in three ways: (1) the amount of change the system can undergo and still retain the same controls on function and structure; (2) the degree to which the system is capable of selforganization; and (3) the ability to build and increase the capacity for learning and adaptation (see Holling 2001, Gunderson and Holling 2002, Folke 2006, and Folke et al. 2010 for an overview of resilience theory, including the adaptive cycle and panarchy).

Although resilience theory is valuable as a metaphor, one area in which it is critically underdeveloped is in metrics (Carpenter et al. 2001, Cumming et al. 2005). The reason that resilience is difficult to operationalize, admit Cumming et al. (2005), is because of its abstract and multi-dimensional nature. Nevertheless, they, and others, attempt to operationalize it. Resilience is an emergent property of systems and can be very context dependent, particularly in spatio-temporal scales and perspectives (Carpenter et al. 2001). A system that is considered resilient today may not be considered so in 50 years, let alone next month, because the internal conditions or the larger system in which it is embedded can and will change. And change can happen suddenly and unexpectedly (Holling 2001). Compounding the difficulty is the fact that resilience in the short term may paradoxically reduce a system's resilience in the long term. In contrast, apparent instability today might build greater resilience for the future (Carpenter et al. 2001, van Apeldoorn et al. 2011). Finally, resilience is not always positive. Systems can become stuck in a cycle of poverty or ecological degradation that is resistant to transformation into a more positive configuration. By its nature and because of our own limitations of comprehension, resilience defies measurement.

In addition to Cumming et al. (2005), other authors have acknowledged the inherent challenges in measuring resilience and propose alternative approaches (Bennett et al. 2005, 
Carpenter et al. 2006, Fletcher et al. 2006, Darnhofer et al. 2010a). Some advocate developing context-dependent surrogates of resilience for each SES to be measured in lieu of resilience itself (e.g., Bennett et al. 2005, Carpenter et al. 2006); others take a more quantified approach such as applying mathematical models (e.g., Fletcher et al. 2006). Yet others focus on creating more conceptual models of SESs, such as the Resilience Assessment Workbook developed by the Resilience Alliance (Resilience Alliance 2010). It takes a stepwise approach to describing the SES in question by first defining its boundaries, framing key issues, and identifying critical thresholds: a process referred to as defining "the resilience of what to what." Answering this question, which was first posed by Carpenter et al. (2001), appears to be a first step in most assessments.

In relation to agroecosystems, however, Darnhofer et al. (2010a:195-196) claim, "farming systems are probably too complex and variable in time and space" for resilience models defined by "resilience of what to what" (as suggested by Carpenter et al. 2001) to provide useful guidance to farmers. "Rather," they conclude, "the value of resilience thinking is more likely to be realized by identifying more general 'rules of thumb' for use by farmers and facilitators to guide farms, the industry sector, the national agricultural system and the interconnected parts of the international food and fiber system towards a more resilient orientation." Furthermore, resilience is an emergent property of a system, arising from the unique interaction between farmer, farm, and context. This implies that no two systems are alike and that what makes one resilient may not necessarily work for another. Agroecosystems embody all the complexity an SES can possibly have, making it nearly impossible to account for every factor that contributes to resilience both now and in the future (Darnhofer et al. 2010a). Darnhofer et al. (2010a) affirm that developing sets of surrogates or indicators, as suggested by Bennett et al. (2005) and Carpenter et al. (2006), is a more useful approach to assessing resilience than trying to measure resilience itself.

Here, we attempt to build on the work of many researchers who have identified characteristics of resilient SESs in many contexts and to apply that body of knowledge to agroecosystems. We agree with Darnhofer et al. (2010a) in their opinion that farming systems are too complex to be measured in any precise way and as such are better served by developing resilience rules of thumb that are applicable across scales of time and space. The difference in this case, however, is that we call them behavior-based indicators (see Carpenter et al. 2001, 2006 for in-depth discussion about the difference between indicators and surrogates) and base our approach on the use of biotic indicators typically employed to monitor ecosystems, although that technique has also been applied to agroecosystems (Büchs 2003). Van der Werf and Petit (2002:139) evaluated 12 such indicator-based methods for assessing sustainability at the farm level and state, "the construction of indicators constitutes an essential step in the establishment of an evaluation method." Clearly, the technique of using indicators is well established.

We present an index of behavior-based indicators that, when identified in an agroecosystem, suggest that it is resilient and endowed with a capacity for adaptation and transformation. The indicators are compiled from characteristics cited most often in literature that deals with resilience in SESs, with a focus on those pertaining to agroecosystems, although not exclusively. Like biotic indicators, the presence of these behavior-based indicators identifies resilience in the system; their absence or disappearance suggests vulnerability and movement away from a state of resilience. We first define the agroecosystem and frame some of the issues relevant to resilience in farming and food systems, i.e., the resilience of what to what. We follow this with descriptions of each indicator and concrete examples gleaned from the literature, coupled with the phase of the adaptive cycle in which it is most critical for the behavior to occur.

\section{THE AGROECOSYSTEM AND RESILIENCE}

The primary purpose of assessing resilience is to identify vulnerabilities in social-ecological systems so that action can be taken to create a more sustainable future for people and the land (Berkes et al. 2003). To do this, we must first define the boundaries of the focal system (Carpenter et al. 2001, Resilience Alliance 2010). Keeping in mind that the system is nested within and connected to other systems, drawing boundaries can be based on biophysical properties (e.g., bioregions, watersheds, etc.) or more abstract demarcations such as political lines, cultural divisions, and differing temporal periods. We use intentionality to bound the agroecosystem (Bland and Bell 2007); as such, the agroecosystem can be defined as an ecosystem managed with the intention of producing, distributing, and consuming food, fuel, and fiber. Its boundaries encompass the physical space dedicated to production, as well as the resources, infrastructure, markets, institutions, and people that are dedicated to bringing food to the plate, fiber to the factory, and fuel to the hearth. The agroecosystem operates simultaneously at multiple nested scales and hierarchies, from the field to the globe. Here, we are concerned with a scale greater than the individual farmer and his or her farm, but a scale small enough that an individual's voice can still make a difference. This is because no farmer operates in a vacuum, and the decisions he or she makes are based in large part on outside influences (Darnhofer et al. 2010b). However, those outside influences should still be subject to feedback from those who are affected by them.

All agroecosystems move through the four phases of the adaptive cycle: growth/exploitation, conservation, release, and reorganization/renewal (Gunderson and Holling 2002, Chapin et al. 2009, Darnhofer et al. 2010b). Just as all SESs 
exist and operate within a nested hierarchy of other systems, so do their adaptive cycles. This nesting of adaptive cycles in a hierarchy is called panarchy (Gunderson and Holling 2002). Various feedback mechanisms and controlling variables, operating in both social and ecological spheres, exert influence on phenomena at higher and lower hierarchical levels. Changes that occur at one spatial and temporal scale do not necessarily match the rate and intensity of changes occurring at another scale, but they invariable influence each other (Darnhofer et al. 2010b). For a more thorough discussion of adaptive cycles and panarchy in the agroecosystem, we refer the reader to Darnhofer et al. (2010b). Essentially, building resilience gives agroecosystems the capacity to maintain the ability to feed and clothe people in the face of shocks while building the natural capital base upon which they depend and providing a livelihood for the people who make it function.

\section{INDEX OF BEHAVIOR-BASED INDICATORS}

We compiled 13 behavior-based indicators from the resilience literature; each is coupled with the phases at which it is most critical to occur. Included in each description is at least one concrete example of what this behavior looks like in practice (Table 1). As is the case with other indicators, systems in which they are present are more likely to be resilient to shocks of different kinds. Their absence or disappearance exposes vulnerabilities or indicates movement away from resilience. This index is applicable to multiple scales and is relevant now and into the future.

\section{Socially self-organized}

\section{Phase in adaptive cycle: reorganization}

The capacity for self-organization is cited as one of the three properties common to all resilient systems (Gunderson and Holling 2002, Folke 2006). Carpenter et al. (2001:778) argue that the degree of self-organization in a given SES is assessed by the extent to which the system managers force a particular configuration as opposed to the components of that system arranging themselves; less interference allows the system to settle into a configuration that is "diverse [and] persistent." However, we argue that self-organization plays a slightly different role in the agroecosystem. The practice of agriculture is concerned primarily with the manipulation of land and biota for the purpose of producing food, fiber, fuel, and other raw materials for human use; the manipulation of the land in the form of tilling, planting, weeding, and harvesting is in a sense a repeated disturbance (Ohlander et al. 1999). If the biophysical components of the agroecosystem are allowed to self-organize following disturbance, they will likely form configurations that are not compatible with human needs (for example, a wheat field giving way to a forest or a garden being engulfed by weeds), but will be very compatible with the needs of the overall ecosystem (Peterson 2009). In that sense, humans still need to maintain a certain degree of control over the biophysical components, and that means limiting the degree to which the ecological half of the SES is capable of self-organization (Swift et al. 2004). However, there is much to be learned by observing how unmanaged ecosystems selforganize following disturbance and applying that model to our own endeavors (see Ecologically self-regulated for more on this).

When viewed from the social perspective, the degree to which farmers, consumers, and other stakeholders can organize themselves is an indicator of a resilient agroecosystem. Individuals, local and regional networks, and smaller institutions of governance can be more responsive and adaptable to changing conditions than can larger groups. Any configuration that they create is more likely to contribute to overall system resilience in the long term because it was created by their own initiative, in response to a real need, and appropriate to their situation. Top-down initiatives can fail if the timing is wrong, if the needs are misinterpreted, or if there is no buy-in from the stakeholders. The timing is usually right for bottom-up initiatives (Folke et al. 1998, Low et al. 2003, Gupta et al. 2010).

One such movement that exemplifies social self-organization is the local food movement in the United States. In the span of 10 years, the volume of direct-to-consumer sales more than doubled, and the number of community-supported agriculture organizations increased from 400 in 2001 to more than an estimated 1400 in 2010 (Martinez et al. 2010). This occurred despite little to no financial or policy support from the top. On the contrary, it has been government policy to encourage larger and more centralized farming operations, not local and decentralized. In response to the success of this grassroots movement and the high demand for local products, lawmakers are working to strengthen policies that encourage localized and diversified food systems (Martinez et al. 2010, Reganold et al. 2011, K. Loria unpublished manuscript).

\section{Ecologically self-regulated}

Phase in adaptive cycle: exploitation to conservation

Carpenter et al. (2001) suggest that agriculturists should not be limited in their ability to organize in ways that improve water quality and biodiversity. As noted above, agroecosystems are different from natural systems in that there must be an intervention by humans for the system to meet our needs. It is possible for farms and food systems that are organized by humans to have the capacity to regulate energy and nutrient flows, control pests, and regenerate with much less need for human intervention than the conventional model of agriculture (Altieri 1999, Ohlander et al. 1999).

A self-regulating agroecosystem, as with any ecosystem, relies on the work of regulating ecosystem services: the hydrological cycle, biodiversity, and soil resources upon which terrestrial communities depend (Luck et al. 2003, Carpenter et al. 2006, Peterson 2009). These regulating services provide the feedback mechanisms that make a system responsive and 
Table 1. Indicators for assessing agroecosystem resilience.

\begin{tabular}{|c|c|c|c|}
\hline Indicator (sources) & Definition & Implications & What to look for \\
\hline $\begin{array}{l}\text { Socially self-organized } \\
\text { (Levin 1999, Holling 2001, } \\
\text { Milestad and Darnhofer 2003, } \\
\text { Atwell et al. 2010, McKey et al. } \\
\text { 2010) }\end{array}$ & $\begin{array}{l}\text { The social components of the } \\
\text { agroecosystem are able to form } \\
\text { their own configuration based on } \\
\text { their needs and desires }\end{array}$ & $\begin{array}{l}\text { Systems that exhibit greater level } \\
\text { of self-organization need fewer } \\
\text { feedbacks introduced by } \\
\text { managers and have greater } \\
\text { intrinsic adaptive capacity }\end{array}$ & $\begin{array}{l}\text { Farmers and consumers are able } \\
\text { to organize into grassroots } \\
\text { networks and institutions such } \\
\text { as co-ops, farmer's markets, } \\
\text { community sustainability } \\
\text { associations, community } \\
\text { gardens, and advisory networks }\end{array}$ \\
\hline $\begin{array}{l}\text { Ecologically self-regulated } \\
\text { (Sundkvist et al. 2005, Ewell } \\
\text { 1999, Jackson 2002, Swift et al. } \\
\text { 2004, Jacke and Toensmeier } 2005 \text {, } \\
\text { Glover et al. 2010, McKey et al. } \\
\text { 2010) }\end{array}$ & $\begin{array}{l}\text { Ecological components self- } \\
\text { regulate via stabilizing feedback } \\
\text { mechanisms that send } \\
\text { information back to the } \\
\text { controlling elements }\end{array}$ & $\begin{array}{l}\text { A greater degree of ecological } \\
\text { self-regulation can reduce the } \\
\text { amount of external inputs } \\
\text { required to maintain a system, } \\
\text { such as nutrients, water, and } \\
\text { energy }\end{array}$ & $\begin{array}{l}\text { Farms maintain plant cover and } \\
\text { incorporate more perennials, } \\
\text { provide habitat for predators } \\
\text { and parasitoids, use ecosystem } \\
\text { engineers, and align production } \\
\text { with local ecological } \\
\text { parameters }\end{array}$ \\
\hline $\begin{array}{l}\text { Appropriately connected } \\
\text { (Axelrod and Cohen 1999, Holling } \\
\text { 2001, Gunderson and Holling } \\
\text { 2002, Picasso et al. 2011) }\end{array}$ & $\begin{array}{l}\text { Connectedness describes the } \\
\text { quantity and quality of } \\
\text { relationships between system } \\
\text { elements }\end{array}$ & $\begin{array}{l}\text { High and weak connectedness } \\
\text { imparts diversity and flexibility } \\
\text { to the system; low and strong } \\
\text { impart dependency and rigidity }\end{array}$ & $\begin{array}{l}\text { Collaborating with multiple } \\
\text { suppliers, outlets, and fellow } \\
\text { farmers; crops planted in } \\
\text { polycultures that encourage } \\
\text { symbiosis and mutualism }\end{array}$ \\
\hline $\begin{array}{l}\text { Functional and response diversity } \\
\text { (Altieri 1999, Ewell 1999, Berkes } \\
\text { et al. 2003, Luck et al. 2003, Swift } \\
\text { et al. 2004, Folke 2006, Jackson et } \\
\text { al. 2007, Di Falco and Chavas }\end{array}$ & $\begin{array}{l}\text { Functional diversity is the variety } \\
\text { of ecosystem services that } \\
\text { components provide to the } \\
\text { system; response diversity is the } \\
\text { range of responses of these }\end{array}$ & $\begin{array}{l}\text { Diversity buffers against } \\
\text { perturbations (insurance) and } \\
\text { provides seeds of renewal } \\
\text { following disturbance }\end{array}$ & $\begin{array}{l}\text { Heterogeneity of features } \\
\text { within the landscape and on the } \\
\text { farm; diversity of inputs, } \\
\text { outputs, income sources, } \\
\text { markets, pest controls, etc. }\end{array}$ \\
\hline
\end{tabular}

2008, Moonen and Barbieri 2008, components to environmental Chapin et al. 2009, Darnhofer et change al. 2010b, McIntyre 2009)

Optimally redundant

\section{Critical components and} relationships within the system are duplicated in case of failure

2005, Darnhofer et al. 2010b,

Walker et al. 2010)

Spatial and temporal heterogeneity (Alcorn and Toledo 1998, Devictor and Jiguet 2007, Di

Falco and Chavas 2008)

Exposed to disturbance (Gunderson and Holling 2002, Berkes et al. 2003, Folke 2006)
Patchiness across the landscape and changes through time

The system is exposed to discrete, low-level events that cause disruptions without pushing the system beyond a critical threshold
Also called response diversity; redundancy may decrease a system's efficiency, but it gives the system multiple back-ups, increases buffering capacity, and provides seeds of renewal following disturbance

Like diversity, spatial heterogeneity provides seeds of renewal following disturbance; through time, it allows patches to recover and restore nutrients

Such frequent, small-scale disturbances can increase system resilience and adaptability in the long term by promoting natural selection and novel configurations during the phase of renewal; described as "creative destruction"

Responsible use of local resources encourages a system to live within its means; this creates an agroecosystem that recycles waste, relies on healthy soil, and conserves water
Planting multiple varieties of crops rather than one, keeping equipment for various crops, getting nutrients from multiple sources, capturing water from multiple sources

Patchiness on the farm and across the landscape, mosaic pattern of managed and unmanaged land, diverse cultivation practices, crop rotations

Pest management that allows a certain controlled amount of invasion followed by selection of plants that fared well and exhibit signs of resistance

Builds (does not deplete) soil organic matter, recharges water, little need to import nutrients or export waste
Swinton 2005, Naylor 2009 ,

Darnhofer et al. 2010a, b, van

Apeldoorn et al. 2011) possible within the means of the bioregionally available natural resource base and ecosystem services 
Reflective and shared learning (Berkes et al. 2003, Darnhofer et al. 2010b, Milestad et al. 2010, Shava et al. 2010)
Individuals and institutions learn from past experiences and present experimentation to anticipate change and create desirable futures
Globally autonomous and locally interdependent (Milestad and Darnhofer 2003, Walker et al. 2010, van Apeldoorn et al. 2011)

Honors legacy

(Gunderson and Holling 2002, Cumming et al. 2005, Shava et al. 2010, van Apeldoorn et al. 2011)

Builds human capital (Buchmann 2009, Shava et al. 2010, McManus et al. 2012)

Reasonably profitable
The system has relative autonomy from exogenous (global) control and influences and exhibits a high level of cooperation between individuals and institutions at the more local level

The current configuration and future trajectories of systems are influenced and informed by past conditions and experiences

The system takes advantage of and builds "resources that can be mobilized through social relationships and membership in social networks" (Nahapiet and Ghoshal 1998:243)

The segments of society involved in agriculture are able to make a livelihood from the work they do without relying too heavily on subsidies or secondary employment
The more people and institutions can learn from the past and from each other, and share that knowledge, the more capable the system is of adaptation and transformation, in other words, more resilient

A system cannot be entirely autonomous but it can strive to be less vulnerable to forces that are outside its control; local interdependence can facilitate this by encouraging collaboration and cooperation rather than competition.

Also known as path dependency, this relates to the biological and cultural memory embodied in a system and its components

Human capital includes: constructed (economic activity, technology, infrastructure), cultural (individual skills and abilities), social (social organizations, norms, formal and informal networks)

Being reasonably profitable allows participants in the system to invest in the future; this adds buffering capacity, flexibility, and builds wealth that can be tapped into following release
Extension and advisory services for farmers; collaboration between universities, research centers, and farmers; cooperation and knowledge sharing between farmers; record keeping; baseline knowledge about the state of the agroecosystem

Less reliance on commodity markets and reduced external inputs; more sales to local markets, reliance on local resources; existence of farmer co-ops, close relationships between producer and consumer, and shared resources such as equipment

Maintenance of heirloom seeds and engagement of elders, incorporation of traditional cultivation techniques with modern knowledge

Investment in infrastructure and institutions for the education of children and adults, support for social events in farming communities, programs for preservation of local knowledge

Farmers and farm workers earn a livable wage; agriculture sector does not rely on distortionary subsidies capable of adapting to both internal and external changes. These maintain the system within a certain range of variability or within a certain domain of attraction (Levin 1999, Sundkvist et al. 2005). The more intact and robust the regulating ecosystem services are, the more resilient the agroecosystem (Peterson 2009).

McKey et al. (2010) studied a landscape in northern South America that was developed by pre-Columbian people and has regulated itself with the aid of ecosystem engineers ever since the sites were abandoned 400-800 years ago. The landscape consists of small mounds dotting a vast seasonally flooded savannah that were built up for the purpose of growing maize and other crops in a polyculture. The mounds provided a dry refuge for crops during the wet season and subsequently were colonized by termites, earthworms, and ants. These became the ecosystem engineers (ecosystem regulators) that have maintained the mounds ever since by cycling nutrients, aerating the soil, moving organic matter to the mounds, and cultivating beneficial fungi. Through the collective action of this team of ecosystem engineers, the mounds contain significantly better soil quality and higher nutrient availability than the surrounding matrix, with consequently greater plant diversity. McKey et al. (2010) suggest that there is potential in further harnessing the work of ecosystem engineers to create agricultural systems that are more capable of self-regulation.

There are numerous examples of contemporary agroecosystems that exhibit a high degree of self-regulation, and research is underway to develop more. These systems have certain common characteristics, first and foremost of which is a maximum amount of soil surface covered by a diverse mix of plants, and to as great extent as practically possible with perennials.

\section{Appropriately connected}

Phase in adaptive cycle: exploitation to conservation

Connectedness refers to the dynamic relationships between elements within a system and between systems across spatial 
and temporal scales. It is not enough to fill an agroecosystem with a diversity of components. Diverse relationships between elements are just as important to resilience as the elements themselves. Resilience theory says that the number and strength of connections within a system and between systems can determine its capacity for adaptation, transformation, and overall responsiveness to changes, thus influencing the system's degree of resilience (Gunderson and Holling 2002). The literature applies two pairs of qualifiers to describe the degree of connectedness in SESs: high vs. low, and strong vs. weak (Holling 2001). High connectedness implies a diversity of relationships between components, whereas low connectedness implies a dearth; strong connectedness makes a system rigid, whereas weak connectedness gives it flexibility.

In an agroecosystem, it is desirable to have a high number of weak connections. Axelrod and Cohen (1999 in Low et al. 2003:104) state, "a design feature to deal with local failures is to avoid having any one element of the system be essential to its overall performance." In practice, appropriate connectedness appears as: farmers collaborating with multiple suppliers and multiple outlets, including consumers, rather than just one; flexibility in laws that enable producers to adapt their practices to local and changing conditions; and access to a labor pool with a wide range of skills. At the farm and field level, one example of appropriate connectedness can be seen in results achieved by cultivating perennial polycultures. Picasso et al. (2011) found that the biomass yield of perennial polycultures improved over time ( $>3 \mathrm{yr}$ ) compared to the same crops planted in monocultures. This is due in part to the complementarity effects the diverse species had on each other as they filled different ecological and functional niches:. This suggests that it was the relationships between the plants (connectedness), not necessarily the plants themselves, that improved yields: a case of the total being greater than the sum of its parts.

\section{High degree of functional and response diversity}

\section{Phase in adaptive cycle: throughout}

Diversity provides both insurance against total system collapse and the seeds of renewal following the release phase of the adaptive cycle (Gunderson and Holling 2002, Berkes et al. 2003). Many authors argue that diversity can reach a saturation point, after which the benefits gained are incremental compared to the potential costs and tradeoffs of maintaining a high level of diversity, e.g., competition for space and light. Rather, building diversity into the system should be more focused on species and species assemblages that perform various functions and differ in their responses to disturbance (Altieri 1999, Ewel 1999, Luck et al. 2003, Swift et al. 2004, Jackson et al. 2007, Di Falco and Chavas 2008, Moonen and Barberi 2008, McIntyre et al. 2009).

The two categories of diversity discussed as critical to the resilience of SESs are functional and response diversity.
Functional diversity refers to the variety of elements and the ecosystem services they provide within the SES (Altieri 1999, Swift et al. 2004, Moonen and Barberi 2008). Each element has a different job in making the system work. Response diversity, as defined by Elmqvist et al. (2003:488), is "the diversity of responses to environmental change among species that contribute to the same ecosystem function." An agroecosystem that contains a high degree of response diversity will be more resilient against various types and degrees of shocks. One example is how various grasses respond to grazing pressure. Another is how grain crops respond to changing climate conditions such as flooding or drought. Di Falco and Chavas (2008) argue that maintaining in-situ crop diversity will be even more important in a future with potentially dramatic climatic swings. Because of genetic variability, greater crop diversity may buffer against shifting rainfall and temperature patterns and possibly reverse downward trends in yields over the long term as they respond differently to such shocks.

\section{Optimally redundant}

Phase in adaptive cycle: conservation to release

Low et al. (2003) write that redundant systems are more capable of transformation and persistence, but only in the right circumstances. Redundancy can have positive or negative connotations, and Low et al. (2003) identify at least five categories of redundancy for various contexts. Common to all, however, are the presence of superfluous units that have some degree of functional overlap within the system. This overlap serves as a buffer against risk and shocks, both for managers and for actors within the system. In any system, there is always a risk that some connection or component such as a supply source or resource will break down and fail. Redundancy assures that there is a backup. The tradeoff, however, is that redundancy can reduce efficiency because it requires an investment in equipment or institutions that may never get used and tie up precious space or resources. However, because disturbance is inevitable and unpredictable, it may pay off in the long run to be prepared (Sundkvist et al. 2005, Darnhofer et al. 2010b, Walker et al. 2010).

Higher up in the hierarchy, Low et al. (2003) suggest that institutions that are organized more in parallel to the structure of ecosystems are more likely to be responsive to the state of the system. A greater degree of cultural or ecological heterogeneity in the landscape or within the country's borders should give rise to greater heterogeneity in governance structures, meaning that they are layered and overlapping. Local institutions gather information and respond rapidly to changes, whereas higher levels provide technical expertise and support during crises. Bill Mollison, founder of the Permaculture movement, summed up redundancy by saying that, in the agroecosystem, each element should serve multiple functions and multiple elements serve a single function (Mollison and Holmgren 1978). 


\section{High degree of spatial and temporal heterogeneity}

Phase in adaptive cycle: growth/exploitation to conservation Heterogeneity in this context is used to describe the lack of uniformity across the landscape and through time. Heterogeneity in an unmanaged landscape results from the work of both biotic and abiotic actors. Microclimates, soil types, disturbance regimes, keystone species, climatic events, and seasonal variations all give rise to patchiness in the landscape. Heterogeneity occurs in agroecosystems as well, though to a lesser degree, and the drivers are more directly anthropogenic in origin. In addition to in-situ crop diversity at the farm scale, Di Falco and Chavas (2008) argue that an agroecosystem with a heterogeneous pattern of land uses and crops, including crop varieties, is more resilient against future climatic changes. Greater heterogeneity in the landscape also supports a higher diversity of species, increasing the capacity for both response and functional diversity. Likewise, the activities of diverse species encourage heterogeneity in otherwise homogeneous landscapes. Heterogeneous landscapes that are well connected with corridors provide habitats for a diversity of plant and animal species, both wild and domesticated, and enable more dynamic relationships between populations (Devictor and Jiguet 2007). This benefits both the agroecosystem and the surrounding wild matrix.

Heterogeneity also has a temporal aspect. People have been practicing shifting cultivation in some locations for possibly thousands of years, and the ecosystem has not been degraded significantly because there is a long break between repetitions of crops. However, as the intensity and frequency of cultivation increase in a certain area, the ecosystem begins to suffer because it never gets a chance to recover and the soil becomes exhausted (Alcorn and Toledo 1998, Naylor 2009). Greater spatial heterogeneity can compensate to a certain degree. In any case, heterogeneity on a smaller scale can spiral up to greater resilience and stability at a higher hierarchical level.

\section{Carefully exposed to disturbance}

Phase in adaptive cycle: release

Disturbance regimes, defined as the repeated exposure to certain shocks over time, push the processes of evolution and adaptation in ecosystems and build ecosystems' capacity to recover from future disturbance (Gunderson and Holling 2002, Folke 2006). As long as the disturbance does not push the ecosystem too close to or beyond a critical threshold, the system can recover and may even be stronger upon reorganization (Fletcher et al. 2006). Disturbance initiates the release of resources that have become sequestered or bound up so that other components can take advantage of them while forming novel configurations; disturbance loosens rigidity.

However, for exposure to disturbance to achieve the desired effect of building resilience, and not the consequence of pushing the system beyond a threshold, the system must be robust, with a strong foundation of ecosystem services and governance. Managed (or unmanaged) properly, disturbance contributes to agroecosystem resilience in two ways. First, it facilitates heterogeneity as described above. Disturbance regimes affect the landscape irregularly, creating a mosaic of plant and animal communities in various stages of succession. Second, it sets into motion the phase of renewal and reorganization. Resources are then redistributed and reorganized into novel configurations that are more adapted to the changing conditions.

One analogy for how the careful introduction of disturbance can build resilience is from the technique of breeding horizontal resistance in crops (van der Plank 1963, Simmonds 1991, Robinson 1996). In the first round of the breeding process, a crop is exposed to a pathogen for which breeders desire resistance. Individual plants that show full resistance are discarded, and plants that are highly susceptible die. Only plants that show partial resistance are bred for the next generation, and the population exhibits a range of resistance to that particular pathogen. With horizontal resistance, some damage and loss is accepted, but overall crop resistance is preserved by the genetic variability of the overall population. In breeding for vertical resistance, on the other hand, only plants with full resistance are selected and back-bred until the population is genetically uniform. No amount of loss or damage is accepted. Resistance, in this case, is either on or off, with no variability. Defense mechanisms function as long as the pathogen does not evolve, but once it does, it can lead to total crop loss. The difference between building horizontal and vertical resistance in crops parallels the long-term benefits gained from carefully introducing disturbance into the agroecosystem.

\section{Responsibly coupled with local natural capital \\ Phase in adaptive cycle: reorganization to exploitation}

Local natural capital refers to the natural resource base and ecosystem services that are found within the agroecosystem's boundaries. In reality, it is difficult to determine the exact size or boundaries of the system in question. Whatever the boundary, modern SESs rely more and more on imported resources while products and byproducts, often in the form of waste and pollution, are exported to regions that cannot afford to mitigate their impacts. In other words, modern SESs are no longer coupled to the natural capital and ecosystem services working within their borders (Ewel 1999, Robertson and Swinton 2005). In the short term, this works, and certain people enjoy a relatively high standard of living. However, this comes at the expense of other SESs and eventually will catch up to everyone, as hinted by changes in the global climate. To wean off dependence on imported resources, SESs should begin to live within the means of the local resource base, including its capacity to convert waste (Milestad and Darnhofer 2003, Darnhofer et al. 2010a,b). This must be done responsibly, however, and not to the point of causing ecosystem collapse, 
as occurs when local resource bases are exhausted. A good entry point for this transition is following a disturbance, during the phase of reorganization, when novel relationships and configurations are still forming.

There are numerous ways in which agroecosystems can be aligned to operate within the means of their natural capital, from practical to political. The agroecosystem should be based on the ecological principle that every waste is a resource. Nitrogen and phosphorous, often imported from outside the region, are applied to boost local production. Farmers do this to compensate for exhausted soils that can no longer manage their own nutrient cycles because little organic matter is returned. Much of that imported nutrition is lost through runoff, seepage, volatization, or exported products, becoming unusable to the local system (van Apeldoorn et al. 2011). Increased reliance on renewable energy sources is another way to couple agroecosystems to local natural capital (Kirschenmann 2010). At the institutional level, governing bodies should implement economic and policy incentives to protect ecosystem services, the slow variables such as soil organic matter, hydrological cycles, and biodiversity, that form the foundation of resilient agroecosystems (Swift et al. 2004, Robertson and Swinton 2005, Naylor 2009). Recoupling farms will have cascading results upward through the agroecosystem and push the greater SES toward resilience.

\section{Reflected and shared learning}

Phase in adaptive cycle: reorganization

The ability to learn from past experiences and share knowledge is what gives an SES its adaptive capacity (Milestad et al. 2010). It allows actors in the system and, by extension, the system itself, to anticipate the future based on experience rather than simply react to present conditions. Within an SES, there are numerous formal and informal institutions that facilitate reflection and shared learning. All of these provide a venue for the discovery and sharing of knowledge and ideas and are crucial to ensure that actors in the agroecosystem are aware of underlying ecological processes and principles such as soil dynamics. Indigenous and local knowledge can also contribute much to scientific research and should be sought when building baseline databases for the state of the agroecosystem (Berkes et al. 2003, Shava et al. 2010).

Milestad et al. (2010) studied the potential for farmer's markets in Sweden to enhance the adaptive capacity in food systems. They concluded that the face-to-face interaction between producers and consumers that takes place at farmer's markets can lead to greater mutual understanding. Farmers learn more about what customers want and how they want their food produced, and consumers learn about the complexities of the food system and where their food comes from. One informs and influences the other, leading to improved practices on the farm and more educated choices by the customer.

\section{Globally autonomous and locally interdependent}

Phase in adaptive cycle: exploitation to conservation Global autonomy is having relative freedom from controls that are outside the agroecosystem's sphere of influence, particularly when it comes to making decisions about how to respond to rapidly changing conditions. International trade agreements, distortionary subsidies, and the far-reaching influence of multi-national corporations and markets increasingly stifle the decision-making process of small-scale, and even large-scale, farmers (Folke et al. 2005). These can inhibit the agroecosystem's flexibility and adaptability as the overarching system becomes increasingly rigid and disconnected (Milestad and Darnhofer 2003, van Apeldoorn et al. 2011).

Milestad and Darnhofer (2003) discuss the influence of regulations, subsidies, and global markets on the organic farming movement and its resilience. They conclude that as currently configured, the above forces tend to diminish, rather than enhance, the resilience and adaptive capacity of the movement. What will turn them from hindering forces to supporting forces is a matter of ownership of the development process and setting the standards; resilience in the movement will begin with resilience on the farm. However, the forces of globalization are not all bad. If one region is hit by disaster such as persistent drought, food and resources can be brought in from abroad to stave off famine. Certain subsidies can guarantee farmers a set price for their commodity even if the market falls out. Trade opens up potentially lucrative markets for producers in poor countries and enhances the flow of information and ideas. These examples highlight the importance of increasing opportunities and cooperation rather than tightening controls.

A counterforce to exogenous controls is the interdependent relationship between actors at a more local level. Local interdependence can fill some of the void that is left from global autonomy. In the absence of external control, it builds trust and encourages cooperation and collaboration among actors. Systems of adaptive governance, or resource comanagement, strive to achieve such collaborative relationships between formal institutions and informal networks in managing resources (see Folke et al. 2005 for a more detailed description of adaptive governance). The same model can be applied to agroecosystems with a greater focus on increasing the adaptive capacity and flexibility of farmers.

\section{Honors legacy while investing in the future}

Phase in adaptive cycle: release to reorganization

The resilience literature talks about path dependency when discussing the potential for future trajectories (Gunderson and Holling 2002). It means that the system's history, or legacy, largely determines its path into the future; as Shakespeare wrote in The Tempest, "What's past is prologue." Legacy is neither good nor bad, but it is a powerful force in shaping 
contemporary SESs, and the legacy we leave will have repercussions long into the future (van Apeldoorn et al. 2011). Legacy is the memory component of the SES and is important for continuity as the system goes through changes because it can be tapped into to build more resilient SESs following disturbance (Cumming et al. 2005).

Legacies can come in the form of culture and traditions, indigenous knowledge, and institutions, but they also come in the form of seed banks and other biophysical resources that we inherit from our predecessors. Heirloom varieties are an important legacy that our ancestors passed down. In addition to taste, they were often bred to tolerate a range of environmental conditions or resist a changing onslaught of pests. That genetic legacy can be invaluable in developing new varieties that tolerate rapidly changing conditions. The knowledge of elders is another form of legacy. They have lived through many changes and learned how to adapt and cope along the way (Shava et al. 2010). They have the advantage of a longer view and are more likely to understand the cyclical nature of life. It is essential that their wisdom, experience, and skills be honored for the sake of future generations.

\section{Builds human capital}

\section{Phase in adaptive cycle: throughout}

Human capital is built upon social resources such as knowledge, skills, and experience that can be mobilized through social relationships and membership in networks (Buchmann 2009, Shava et al. 2010). It is like a bank account, but rather than being filled with money, it is filled with collective knowledge about how the world works. The more the account is filled with this knowledge, the more return it gets on an investment. In the agroecosystem, humans play a keystone role by influencing their environment to greater and lesser degrees. Both halves of the SES benefit if that influencing role is enacted by a well-informed, wellconnected, and well-supported populace.

Buchmann (2009) studied the role of home gardens in building resilience in Cuba and cited the central role of social and cultural capital in increasing adaptive capacity and buffering against the unpredictable political and economic climate. Because of isolation resulting from the trade embargo, Cubans have had to rely on their own networks and knowledge to maintain a sufficient local food supply. Without support from foreign institutions, Cubans have learned how to be more selfsufficient and resourceful by tapping into already existing social networks and traditional knowledge. Of course, all that may change if the embargo is lifted and there is no longer a need for home gardens. At that point, Cuba will enter a period of reorganization, but it will most likely benefit from the rich social and cultural capital that has supported it so far. More specific ways in which an agroecosystem can invest in human capital is to provide meeting places for socializing, encourage multi-generational interaction, give opportunities for participants to develop, and build trust (McManus et al. 2012).

\section{Reasonably profitable}

Phase in adaptive cycle: conservation

Profitability is another word for the accumulation of wealth, something that occurs during the conservation phase of the adaptive cycle. As Holling (2001) pointed out, the accumulation of wealth simultaneously increases a system's potential for resilience and its vulnerability. As financial and natural wealth becomes sequestered, it is less available to other components. Ironically, the more wealthy and rigid an SES becomes, the more resources will be available to the system following release and the better it can recover through reorganization.

If agroecosystems are to continue to meet human needs, those who manage them must have their needs met as well. Farmers and farm workers should be able to make a living from work directly related to their labor, if they want to, without depending too much on off-farm income or subsidies. This could reduce the level of burn-out and rural flight seen in both developing and developed economies. At one extreme, farms in Norway receive as much as $70 \%$ of gross output in the form of subsidies (Organisation for Economic Co-operation and Development 2009), yet 79\% of farmers also work outside the farm (Eurostat 2011). Despite the high level of support, by all indicators, the number of farmers and the area under cultivation in Norway is in decline.

One of the reasons poor farmers push the land beyond what it can handle is to squeeze more profit out of it as the costs of production rise and market prices fall. Numerous factors contribute to this trend, from market forces and shifting demographics to land tenure, but the outcome is shorter fallow periods, overextension of water and soil resources, and greater reliance on external inputs such as fertilizers. At the same time, farmers in wealthier nations feel pressure to increase the size of operations to compete in the global market, pushing them to invest in larger equipment, increase yields (through intensification or extensification), and rely more on external inputs. Farmers should be able to make a livelihood from their efforts while concurrently acting as stewards of the land.

\section{CONCLUSION}

The time for building resilience in the agroecosystem has never been more critical or more difficult. The increasing complexity and larger stakes of the system confound our best efforts to put into practice what we know can work. While the theory of resilience in social-ecological systems provides some insights into this complexity, there are still limitations in our capacity to do anything about it. One of those limitations is in knowing where the system stands and if our efforts are moving it toward or away from increased resilience. Some argue that the best way to track progress is to develop precise metrics for measuring resilience. However, despite the attempts of many, measuring resilience in social-ecological systems has proven to be like aiming at a moving target. We agree with those who advocate for developing less precise rules of thumb and in that 
vein have compiled an index of behavior-based indicators of resilience in the agroecosystem. These indicators identify behaviors that, when present, imply that the system is more capable of persisting in its ability to meet the food, fuel, and fiber needs of humans well into the future. Absence or disappearance of these behaviors signals vulnerability in the agroecosystem and a need for intervention.

Responses to this article can be read online at:

http://www.ecologyandsociety.org/vol17/iss 1/art18/

responses/

\section{Acknowledgments:}

We thank those who contributed comments and feedback during the process of developing arguments and writing this article, particularly Årolilja Jorgensrud and several anonymous reviewers.

\section{LITERATURE CITED}

Alcorn, J. B., and V. M. Toledo. 1998. Resilient resource management in Mexico's forest ecosystems: the contribution of property rights. Pages 213-249 in F. Berkes and C. Folke, editors. Linking social and ecological systems: management practices and social mechanisms for building resilience. Cambridge University Press, Cambridge, UK.

Altieri, M. A. 1999. The ecological role of biodiversity in agroecosystems. Agriculture, Ecosystems and Environment 74 (1-3):19-31. http://dx.doi.org/10.1016/S0167-8809(99)00028-6

Atwell, R. C., L. A. Schulte, and L. M. Westphal. 2010. How to build multifunctional agricultural landscapes in the US Corn Belt: add perennials and partnerships. Land Use Policy 27 (4):1082-1090. http://dx.doi.org/http://dx.doi.org/10.1016/j.la ndusepol.2010.02.004

Axelrod, R. M., and M. D. Cohen. 1999. Harnessing complexity: organizational implications of a scientific frontier. Free Press, New York, New York, USA.

Bennett, E. M., G. S., Cumming, and G. D. Peterson. 2005. A systems model approach to determining resilience surrogates for case studies. Ecosystems 8(8):945-957. http://dx.doi.org/1 $\underline{0.1007 / \mathrm{s} 10021-005-0141-3}$

Berkes, F., J. Colding, and C. Folke, editors. 2003. Navigating social-ecological systems: building resilience for complexity and change. Cambridge University Press, Cambridge, UK.

Bland, W. L., and M. M. Bell. 2007. A holon approach to agreoecology. International Journal of Agricultural Sustainability 5(4):280-294.

Buchmann, C. 2009. Cuban home gardens and their role in social-ecological resilience. Human Ecology 37(6):705-721. http://dx.doi.org/10.1007/s10745-009-9283-9
Büchs, W. 2003. Biodiversity and agri-environmental indicators-general scopes and skills with special reference to the habitat level. Agriculture, Ecosystems and Environment 98(1-3):35-78. http://dx.doi.org/10.1016/S0167-8809(03)00070-7

Carpenter, S. R., E. M. Bennett, and G. D. Peterson. 2006. Scenarios for ecosystem services: an overview. Ecology and Society 11(1): 29. [online] URL: http://www.ecologyandsociety. org/vol11/iss1/art29/.

Carpenter, S., B. Walker, J. M. Anderies, and N. Abel. 2001. From metaphor to measurement: Resilience of what to what? Ecosystems 4(8):765-781. http://dx.doi.org/http://dx.doi.org/1 $\underline{0.1007 / \mathrm{s} 10021-001-0045-9}$

Chapin III, F. S., G. P. Kofinas, and C. Folke, editors. 2009. Principles of ecosystem stewardship: resilience-based natural resource management in a changing world. First edition. Springer, New York, New York, USA.

Cumming, G. S., G. Barnes, S. Perz, M. Schmink, K. E. Sieving, J. Southworth, M. Binford, R. D. Holt, C. Stickler, and T. Van Holt. 2005. An exploratory framework for the empirical measurement of resilience. Ecosystems 8 (8):975-987. http://dx.doi.org/10.1007/s10021-005-0129-z

Darnhofer, I., S. Bellon, B. Dedieu, and R. Milestad. 2010a. Adaptiveness to enhance the sustainability of farming systems: a review. Agronomy for Sustainable Development 30 (3):545-555. http://dx.doi.org/http://dx.doi.org/10.1051/agro/ $\underline{2009053}$

Darnhofer, I., J. Fairweather, and H. Moller. 2010b. Assessing a farm's sustainability: insights from resilience thinking. International Journal of Agricultural Sustainability 8 (3):186-198. http://dx.doi.org/http://dx.doi.org/10.3763/ijas.2 $\underline{010.0480}$

Devictor, V., and F. Jiguet. 2007. Community richness and stability in agricultural landscapes: the importance of surrounding habitats. Agriculture, Ecosystems and Environment 120(2-4):179-184. http://dx.doi.org/10.1016/j.agee.2006.08.013

Di Falco, S., and J. P. Chavas. 2008. Rainfall shocks, resilience, and the effects of crop biodiversity on agroecosystem productivity. Land Economics 84(1):83-96.

Elmqvist, T., C. Folke, M. Nystrom, G. Peterson, J. Bengtsson, B. Walker, and J. Norberg. 2003. Response diversity, ecosystem change, and resilience. Frontiers in Ecology and the Environment 1(9):488-494. http://dx.doi.org/10.1890/154 0-9295(2003)001[0488:RDECAR]2.0.CO;2

Ericksen, P. J. 2008. Conceptualizing food systems for global environmental change research. Global Environmental Change 18(1):234-245. http://dx.doi.org/10.1016/j.gloenvcha $\underline{.2007 .09 .002}$ 
Eurostat. 2011. Farm structure in Norway. European Commission, Luxembourg. [online] URL: http://epp.eurostat. ec.europa.eu/statistics explained/index.php/Farm structure in_Norway.

Ewel, J. J. 1999. Natural systems as models for the design of sustainable systems of land use. Agroforestry Systems 45 (1-3):1-21. http://dx.doi.org/http://dx.doi.org/10.1023/A:1006 $\underline{219721151}$

Fletcher, C. S., C. Miller, and D. W. Hilbert. 2006. Operationalizing resilience in Australian and New Zealand agroecosystems. In Proceedings of the 50th Annual Meeting of the ISSS, ISSS 2006 Papers. Journals ISSS. [online] URL: http://journals.isss.org/index.php/proceedings50th/article/view/355

Folke, C. 2006. Resilience: the emergence of a perspective for social-ecological systems analyses. Global Environmental Change 16(3):253-267. http://dx.doi.org/10.1016/j.gloenvcha .2006 .04 .002

Folke, C., F. Berkes, and J. Colding. 1998. Ecological practices and social mechanisms for building resilience and sustainability. Pages 414-436 in F. Berkes, C. Folke, and J. Colding, editors. Linking social and ecological systems: management practices and social mechanisms for building resilience. Cambridge University Press, Cambridge, UK.

Folke, C., S. R. Carpenter, B. Walker, M. Scheffer, T. Chapin, and J. Rockström. 2010. Resilience thinking: integrating resilience, adaptability and transformability. Ecology and Society 15(4): 20. [online] URL: http://www.ecologyandsociety. org/vol15/iss4/art20/.

Folke, C., T. Hahn, P. Olsson, and J. Norberg. 2005. Adaptive governance of social-ecological systems. Annual Review of Environment and Resources 30:441-473. http://dx.doi.org/10 .1146/annurev.energy.30.050504.144511

Gliessman, S. R. 2007. Agroecology: the ecology of sustainable food systems. CRC Press, Boca Raton, Florida, USA.

Glover, J. D., J. P. Reganold, L. W. Bell, J. Borevitz, E. C. Brummer, E. S. Buckler, C. M. Cox, T. S. Cox, T. E. Crews, S. W. Culman, L. R. DeHaan, D. Eriksson, B. S. Gill, J. Holland, F. Hu, B. S. Hulke, A. M. H. Ibrahim, W. Jackson, S. S. Jones, S. C. Murray, A. H. Paterson, E. Ploschuk, E. J. Sacks, S. Snapp, D. Tao, D. L. van Tassel, L. J. Wade, D. L. Wyse, and Y. Xu. 2010. Increased food and ecosystem security via perennial grains. Science 328:1638-1639. http://dx.doi.or $\mathrm{g} / 10.1126 /$ science. 1188761

Gunderson, L. H., and C. S. Holling. 2002. Panarchy: understanding transformations in human and natural systems. Island Press, Washington, D.C., USA.
Gupta, J., C. Termeer, J. Klostermann, S. Meijerink, M. van den Brink, P. Jong, S. Nooteboom, and E. Bergsma. 2010. The Adaptive Capacity Wheel: a method to assess the inherent characteristics of institutions to enable the adaptive capacity of society. Environmental Science and Policy 13(6):459-471. http://dx.doi.org/10.1016/j.envsci.2010.05.006

Holling, C. S. 1973. Resilience and stability of ecological systems. Annual Review of Ecology and Systematics 4:1-23. http://dx.doi.org/10.1146/annurev.es.04.110173.000245

Holling, C. S. 2001. Understanding the complexity of economic, ecological, and social systems. Ecosystems 4 (5):390-405. http://dx.doi.org/10.1007/s10021-001-0101-5

Jacke, D., and E. Toensmeier. 2005. Edible forest gardens. Chelsea Green Publishing, White River Junction, Vermont, USA.

Jackson, L. E., U. Pascual, and T. Hodgkin. 2007. Utilizing and conserving agrobiodiversity in agricultural landscapes. Agriculture, Ecosystems and Environment 121(3):196-210. http://dx.doi.org/10.1016/j.agee.2006.12.017

Jackson, W. 2002. Natural systems agriculture: a truly radical alternative. Agriculture, Ecosystems and Environment 88 (2):111-117. http://dx.doi.org/10.1016/S0167-8809(01)00247$\underline{X}$

Kirschenmann, F. 2010. Alternative agriculture in an energyand resource-depleting future. Renewable Agriculture and Food Systems 25(2):85-89. http://dx.doi.org/10.1017/S17421 $\underline{70510000141}$

Levin, S. A. 1999. Fragile dominion: complexity and the commons. Perseus Books, Reading, Massachusetts, USA.

Low, B., E. Ostrom, C. Simon, and J. Wilson. 2003. Redundancy and diversity: do they influence optimal management? Pages 83-114 in F. Berkes, J. Colding, and C. Folke, editors. Navigating social-ecological systems: building resilience for complexity and change. Cambridge University Press, Cambridge, UK.

Luck, G. W., G. C. Daily, and P. R. Ehrlich. 2003. Population diversity and ecosystem services. Trends in Ecology and Evolution 18(7):331-336. http://dx.doi.org/10.1016/S0169-5347 (03)00100-9

Martinez, S., M. Hand, M. Da Pra, S. Pollack, K. Ralston, T. Smith, S. Vogel, S. Clark, L. Lohr, S. Low, and C. Newman. 2010. Local food systems: concepts, impacts, and issues. Economic Research Report 97. U.S. Department of Agriculture, Economic Research Service, Washington, D.C., USA. [online] URL: http://www.ers.usda.gov/publications/err97/

McIntyre, B. D., H. R. Herren, J. Wakhungu, and R. T. Watson, editors. 2009. Agriculture at a crossroads: International 
Assessment of Agricultural Knowledge, Science and Technology for Development (IAASTD): global report. Island Press, Washington, D.C., USA. [online] URL: http://www.ag assessment.org/reports/IAASTD/EN/Agriculture\%20at\%20a\% 20Crossroads Global\%20Report\%20(English).pdf.

McKey, D., S. Rostain, J. Iriarte, B. Glaser, J. J. Birk, I. Holst, and D. Renard. 2010. Pre-Columbian agricultural landscapes, ecosystem engineers, and self-organized patchiness in Amazonia. Proceedings of the National Academy of Sciences 107(17):7823-7828. http://dx.doi.org/10.1073/pnas.0908925107

McManus, P., J. Walmsley, N. Argent, S. Baum, L. Bourke, J. Martin, B. Pritchard, and T. Sorensen. 2012. Rural community and rural resilience: What is important to farmers in keeping their country towns alive? Journal of Rural Studies 28(1):20-29. http://dx.doi.org/http://dx.doi.org/10.1016/j.jrur $\underline{\text { stud.2011.09.003 }}$

Milestad, R., and I. Darnhofer. 2003. Building farm resilience: the prospects and challenges of organic farming. Journal of Sustainable Agriculture 22(3):81-97. http://dx.doi.org/10.1300/ J064v22n03_09

Milestad, R., L. Westberg, U. Geber, and J. Björklund. 2010. Enhancing adaptive capacity in food systems: learning at farmers' markets in Sweden. Ecology and Society 15(3): 29. [online] URL: http://www.ecologyandsociety.org/vol15/iss3/ art29/.

Millennium Ecosystem Assessment. 2005. Ecosystems and human well-being: synthesis. Island Press, Washington, D.C., USA.

Mollison, B. C., and D. Holmgren. 1978. Permaculture 1: a perennial agricultural system for human settlements. Transworld Publishers, Melbourne, Australia.

Moonen, A.-C., and P. Barberi. 2008. Functional biodiversity: an agroecosystem approach. Agriculture, Ecosystems and Environment 127(1-2):7-21. http://dx.doi.org/10.1016/j.agee. 2008.02.013

Nahapiet, J., and S. Ghoshal. 1998. Social capital, intellectual capital, and the organizational advantage. Academy of Management Review 23(2):242-266.

Naylor, R. L. 2009. Managing food production systems for resilience. Pages 259-280 in F. S. Chapin III, G. P. Kofinas, and C. Folke, editors. Principles of ecosystem stewardship: resilience-based natural resource management in a changing world. Springer, New York, New York, USA. http://dx.doi.o rg/10.1007/978-0-387-73033-2_12

Ohlander, L., C. Lagerberg, and U. Gertsson. 1999. Visions for ecologically sound agricultural systems. Journal of Sustainable Agriculture 14(1):73-79. http://dx.doi.org/10.1300/ J064v14n01 07
Organisation for Economic Co-operation and Development 2009. Agricultural policies in OECD countries: monitoring and evaluation. OECD, Paris, France. [online] URL: http://w ww.oecd.org/dataoecd/37/16/43239979.pdf.

Peterson, G. 2009. Ecological limits of adaptation to climate change. Pages 25-41 in W. N. Adger, I. Lorenzoni, and K. L. O'Brien, editors. Adapting to climate change: thresholds, values, governance. Cambridge University Press, Cambridge, UK. http://dx.doi.org/10.1017/CBO9780511596667.003

Picasso, V. D., E. C. Brummer, M. Liebman, P. M. Dixon, and B. J. Wilsey. 2011. Diverse perennial crop mixtures sustain higher productivity over time based on ecological complementarity. Renewable Agriculture and Food Systems 26(4):317-327. http://dx.doi.org/10.1017/S1742170511000135

Reganold, J. P., D. Jackson-Smith, S. S. Batie, R. R. Harwood, J. L. Kornegay, D. Bucks, C. B. Flora, J. C. Hanson, W. A. Jury, D. Meyer, A. Schumacher Jr., H. Sehmsdorf, C. Shennan, L. A. Thrupp, and P. Willis. 2011. Transforming U.S. agriculture. Science 332:670-671. http://dx.doi.org/10.1126/s cience. 1202462

Resilience Alliance. 2010. Assessing resilience in socialecological systems: workbook for practitioners. Version 2.0. Resilience Alliance. [online] URL: http://www.resalliance.org/ index.php/resilience assessment.

Robertson, G. P., and S. M. Swinton. 2005. Reconciling agricultural productivity and environmental integrity: a grand challenge for agriculture. Frontiers in Ecology and the Environment 3(1):38-46. http://dx.doi.org/10.1890/1540-9295 (2005)003[0038:RAPAEI]2.0.CO;2

Robinson, R. A. 1996. Return to resistance: breeding crops to reduce pesticide dependence. AgAccess, Davis, California, USA, and International Development Research Centre, Ottawa, Canada. [online] URL: http://web.idrc.ca/openebook s/774-4/. http://dx.doi.org/10.1016/S0167-8809(97)87015-6

Shava, S., M. E. Krasny, K. G. Tidball, and C. Zazu. 2010. Agricultural knowledge in urban and resettled communities: applications to social-ecological resilience and environmental education. Environmental Education Research 16(5-6):575-589. http://dx.doi.org/10.1080/13504622.2010.505436

Simmonds, N. W. 1991. Genetics of horizontal resistance to diseases of crops. Biological Reviews 66(2):189-241. http://d x.doi.org/10.1111/j.1469-185X.1991.tb01140.X

Sundkvist, A., R. Milestad, and A. M. Jansson. 2005. On the importance of tightening feedback loops for sustainable development of food systems. Food Policy 30(2):224-239. http://dx.doi.org/10.1016/j.foodpol.2005.02.003 
Swift, M. J., A. M. N. Izac, and M. van Noordwijk. 2004. Biodiversity and ecosystem services in agricultural landscapes - are we asking the right questions? Agriculture, Ecosystems and Environment 104(1):113-134. http://dx.doi.org/10.1016/j. agee.2004.01.013

Van Apeldoorn, D. F., K. Kok, M. P. W. Sonneveld, and T. A. Veldkamp. 2011. Panarchy rules: rethinking resilience of agroecosystems, evidence from Dutch dairy-farming. Ecology and Society 16(1): 39. [online] URL: http://www.ecologyand society.org/vol16/iss1/art39/.

Van der Plank, J. E. 1963. Plant diseases: epidemics and control. Academic Press, New York, New York, USA.

Van der Werf, H. M. G., and J. Petit. 2002. Evaluation of the environmental impact of agriculture at the farm level: a comparison and analysis of 12 indicator-based methods. Agriculture, Ecosystems and Environment 93(1-3):131-145. http://dx.doi.org/10.1016/S0167-8809(01)00354-1

Walker, B., J. Sayer, N. L. Andrew, and B. Campbell. 2010. Should enhanced resilience be an objective of natural resource management research for developing countries? Crop Science 50(2):S10-S19. 